\title{
Cirebon Society's Perception about Kasepuhan Palace in Creating Kasepuhan Palace to International Destination
}

\author{
Farida Nurfalah \\ Faculty of Social Science and Political Science \\ University of Swadaya Gunung Jati, Cirebon, West Java, Indonesia \\ Pemuda Street 32, Cirebon \\ E-mail: Faridanurfalah2@yahoo.com
}

\begin{abstract}
The readiness of a tourist destination to perform go international starting from within the destination with the quality and facilities, as well as the readiness of society and the professionalism of existing human resources. Problem identification in this research is as follows: 1). How is the Cirebon Society's Perception about Kasepuhan Palace ?. 2). How is Cirebon Society's Perception about Kasepuhan Palace towards International Tourism Destination ?. 3). How is the factor supporting to Kasepuhan Palace towards the International Tourism Destination ?. 4). How is the constraint factor Kasepuhan Palace towards International Tourism Destination ?. The method used in this research is the descriptive method with the qualitative approach. The results explain that 1). Kasepuhan Palace is one of the royal buildings in its time, which looks beautiful but slightly mystique, the people around friendly, the royal palace is very polite, a clean building is very well maintained, as an icon of Cirebon and regional assets. 2. Cirebon Society's Perception about Kasepuhan Palace to International Destination can scent the Cirebon area. 3). Inhibiting factors are about environmental conditions and maintenance of the originality of buildings. 4). The supporting factors of Kasepuhan Palace have prepared themselves through the use of economic, social, cultural, art, entrepreneurship, and technology resources by forming community organizations and supporting tourism education and training.
\end{abstract}

Keywords: Perception, Destination

\section{INTRODUCTION}

One of the mainstay sectors of the government to become the driving force of the regional economy is the tourism industry. The tourism industry in Indonesia has enormous potential to develop as it is supported by the increasing trend of traveling among the public. Based on the concepts conveyed by Mill and Morrison (2002: xvii), tourism is an activity related to all aspects of tourism, travel, leisure, and leisure, whereas the word international is defined as an activity that crosses a country's boundaries. So international tourism is defined as a journey that travels across a country's boundaries in order to have fun without earning a living and using its own funds.

The readiness of a tourist destination to perform go to international starting from within the destination. This readiness is shown by the quality of attractions owned, the completeness of facilities to support tourism activities, adequate access, as well as the readiness of society and human resources professionals in these destinations, to actively plunge and support the industry. In order to meet these four criteria, the stakeholders of the tourist destination should give positive support to the development of the destination. Destinations also need to examine and recognize well the potential of the market owned.

After the fourth amendment of the 1945 Constitution, Article 32 of the 1945 Constitution reads:
1. The State promotes the national culture of Indonesia in the midst of the civilization of the world by ensuring the freedom of society in maintaining and developing its cultural values.

2. The State respects and maintains the regional language as a national cultural treasure.

The provision provides guidance on a new cultural strategy on state obligations to:

1. Promoting the national culture in a global culture and in an atmosphere of globalization. The State shall defend and protect the national culture of the Indonesian nation from being eliminated in the struggle for civilization.

2. Providing "authority" to the people of the nation and region to develop nurture their respective cultures.

3. Respect and preserve the local languages, which now preserved various ethnic groups as one of their identities within the framework of a nationally recognized cultural richness.

These principles require more operational elaboration in the strategy of developing national culture and local culture in a global setting. The clarity of national and regional cultural development strategies is very important since the enactment of Law no. 32 of 2004, local government has given freedom to the regions to manage their own households, including in the cultural and tourism sectors. On this basis, local 
governments have the authority to manage cultural heritage in order to preserve the past with the present and future sustainability, advance civilization, develop national identity and authority and make it a source of public income through tourism activities.

http://disporbudpar.cirebonkota.go.id/kultur/bu daya/69-trip-waras.html

Kasepuhan Palace, as one of the central government of Cirebon Sultanate since 1985 prepares to make Cirebon as an international tourist destination. If previously managed traditionally, according to the times, the palace Kasepuhan finally add its function as a tourist attraction. Apart from being a center of civilization and cultural center, Cirebon is also a socialization of Islam. As in ancient times, Port of Cirebon was known as the center of international trade. The emergence of travel agents, the rise of the hospitality industry, the development of the culinary industry, the emergence of various literature on tourism business, and the development of tourist destinations, this time Cirebon has been visited by many foreign tourists. Almost every month there is a cruise ship that basic and brings a group of tourists from Europe and France.

Department of Youth Sports Culture and Tourism (Disporbudpar) Cirebon recorded the level of foreign tourist arrivals during 2015 rose $75 \%$ or reached 6,831 people throughout 2015 . In 2014, the level of foreign tourists visit only reached 1710 people. Overall, tourist arrivals to the city of Cirebon during 2015 reached 481,223 people for domestic tourists, while foreign tourists reached 6,831 people. (Mukarto, et al, 2016: 63) Kasepuhan Palace Cirebon is an important historical site as the center of government as well as the center of spreading Islam in West Java. In the year 2017, Keraton Kasepuhan became the host of the Palace Festival Nusantara XI. (Radar Cirebon, 2015). Therefore in this study discusses how the Cirebon City Perception of Kasepuhan Palace in Creating Kasepuhan Palace to the International Tourism Destination so that we can know the identification problem as follows: 1). How is the perception of Cirebon city community about Keraton Kasepuhan? ; 2). How is the perception of Cirebon city community about Keraton Kasepuhan in creating Kasepuhan Palace to International Tourism Destination? ; 3). How are the factors supporting the Kasepuhan Palace in Creating the Kasepuhan Palace to the International Tourism Destination ?; 4). How is the constraint factor of Kasepuhan Palace in
Creating Kasepuhan Palace to International Tourism Destination?

\section{LITERATURE REVIEW}

\section{A Review of Perception}

Perception is at the core of a communication whereas perceptual interpretation is an internal process that allows us to choose, organize and interpret stimuli from our environment and that process influences our behavior. Perception includes sensation through our sense devices (sense of touch, sense of sight, sense of smell, sense of taste and sense of listener), attention, and interpretation. Sensation refers to messages sent to the brain through sight, hearing, touch, smell, and tasting. Attention is inevitable before we respond or interpret any event or stimulus, we must first pay attention to the incident or stimulus. The most important stage in perception is the interpretation of the information we gain through one or more of our senses. (Mulyana, 2007: 180).

\section{B. Reviews About Tourism}

The criteria of tourist destinations in Yulia when they are ready to be marketed and developed into international excellent destinations are:

1. Attractions or tourist attractions that include natural attractions, man-made attractions, and event attractions that become the object and purpose of tourist visits.

2. Accessibility

Tourism accessibility is defined as the entrance and exit to and from tourist destinations.

I. Stakeholder support

Destination managers include governments, tourism associations, communities, and investors or entrepreneurs in these destinations to provide support and participation to advance destinations.

3. Tourism facilities and accommodation Which is a means and infrastructure of tourism supporters to be able to improve the quality and value of the attraction of these tourist destinations? Businesses capable of supporting complementary tourism facilities include accommodation business, food and beverage business, tourism services business, recreation or entertainment business, and tourism business. Facilities that can deliver more value than other destinations include 
meeting facilities and exhibition facilities as well.

4. The image of the destination needs to get special attention through good management will add attraction so as to increase the visit.

5. Community readiness and HR professionalism

The participation of the community in the development of tourism destinations can include active participation in tourism development, increased tourism awareness, actively conveying advice and aspirations, extracting economic, social, cultural, art, entrepreneurial, and technological resources to build the destination, establishing community organizations to help development of tourist areas, and participate and support tourism education and awareness.

6. Potential market owned with the total coverage area of the marketing of these tourist destinations. the better the potential of a destination is then able to attract tourists and attract investors to invest their business in the area.
7. According to Kotler and Armstrong (2008: 250), positioning is an activity that will differentiate products and brands from competitors of the mind consumer based on the attributes or benefits offered brand or product. Positioning Toward Self (Positioning Toward Consumer (Brand Considering Brand), Positioning Toward Competitor (how competitors see brand).

\section{RESEARCH METHODS}

The method that writer use in this research is the descriptive method to explain and describe phenomena that happened. This study did not seek or explain the relationship, did not test the hypothesis or make predictions (Rachmat, 2000: 24). The approach used in this research is the qualitative approach that is more holistic, inductive and naturalistic, while the type of research used is a descriptive-qualitative type. Research subjects of the informants of this study are determined based on purposive techniques, because there is no sampling frame of all elements contained in the informant, including Disporbudpar Representative, Society, and the Palace.

The operationalization framework concept of this study are as follows:

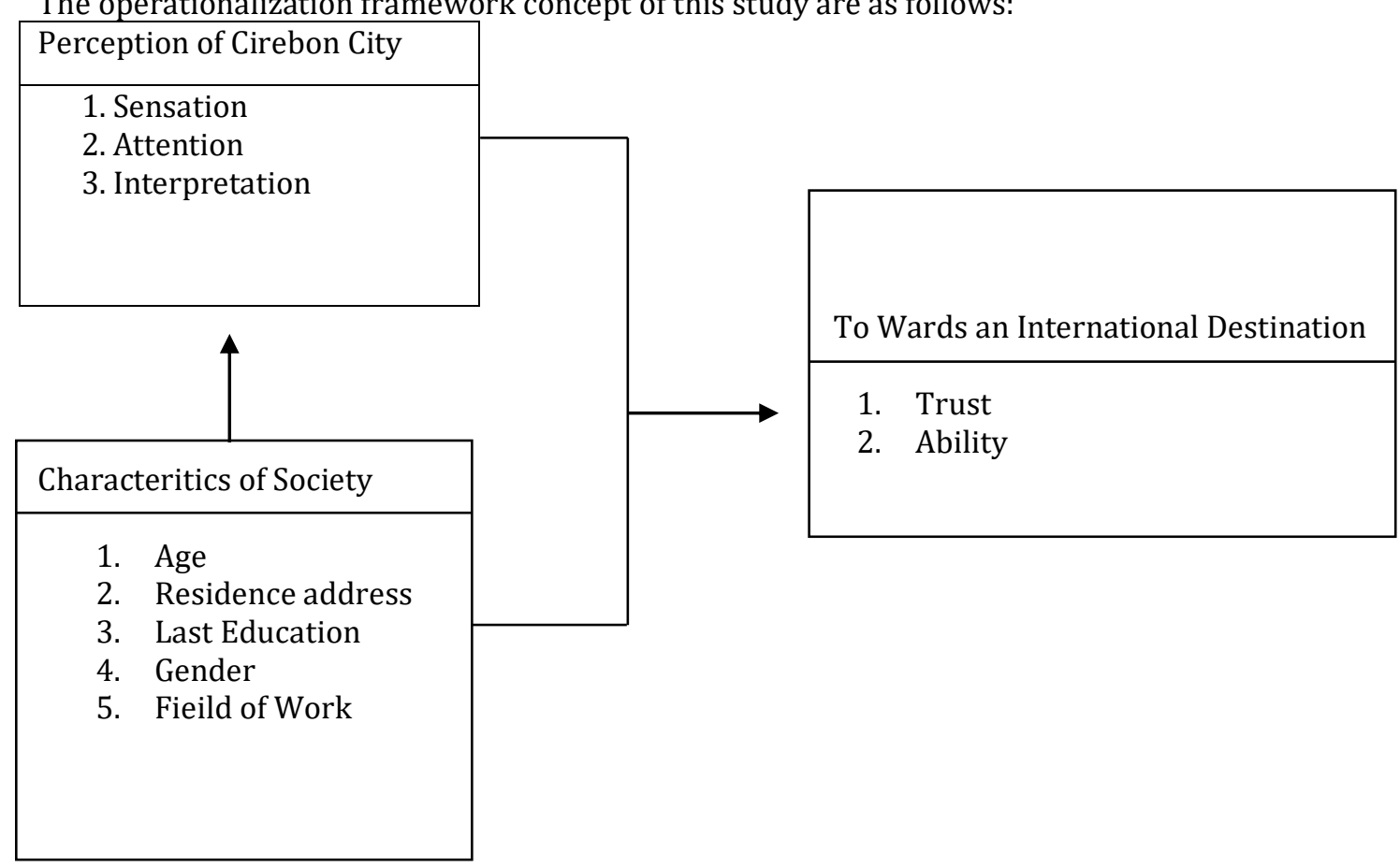

Figure 1.1 Framework for Perception of the Cirebon City society about Kasepuhan Palace in Creating Kasepuhan Palace to the International Destination Destination 


\section{RESULTS AND DISCUSSION}

Researchers have limited research informants as many as eight people. The informant profile is as follows :

Table 4.1.

Profile of Informant

\begin{tabular}{|l|l|l|l|l|}
\hline NO & NAME & OF ORIGIN AGENCY & USIA & TYPES OF SEX \\
\hline 1 & SL (1) & Argasunya & 21 Years & Women \\
\hline 2 & AY (2) & Kesambi & 33 Years & Women \\
\hline 3 & FB (3) & Kesambi & 36 Years & Men \\
\hline 4 & HD (4) & Kesambi & 23 Years & Men \\
\hline 5 & JM (5) & Dukuhsemar & 22 Years & Men \\
\hline 6 & SR (6) & Pemuda & 27 Years & Men \\
\hline 7 & $\begin{array}{l}\text { Iman } \\
\text { Sugiman }\end{array}$ & PR Keraton Kasepuhan & 52 Years & Men \\
\hline 8 & $\begin{array}{l}\text { Sugiono, } \\
\text { S.Pd }\end{array}$ & Disporbudpar & 47 Years & Men \\
\hline
\end{tabular}

Source: Result of research, 2017

Here are the results of research by conducting interviews with several resource persons related to research:

4.1.Perception of Cirebon City People about Kasepuhan Palace

\subsubsection{Sensation}

The sensation in Kasepuhan Palace according to the informant is as follows:

Interview with Informant I:

"From the outside looks beautiful but a bit mystical look, nevertheless the life of the people of the palace is very well-knit and very knowledgeable about the Kasepuhan palace so as Visitors are very helpful with the friendly community." (Interview: July 7, 2017)

Informant II perceived from the aspect of the sensation of the palace Kasepuhan looked "beautiful and artistic" as well as the perception of informants III "Megah dan Indah" and Informant IV said "Beautiful and the building is still well ordered", while Information V said "Seen in the environment around the palace as a royal building in its mass and until now a sacred place believed to have a positive magical power." Added the statement of Informant II, that Keraton Kasepuhan becomes one of the palaces in Cirebon that should have the power in decision making to welfare its people still have not felt the impact, the palace is only a tourist attraction and do not have political power ". Informant III declares it as a building of the Kasepuhan empire of its time, and until now it is a sacred place believed to have a positive magical power. Thus Kasepuhan Palace has its own sensation for the community both from the building, culture, and social interaction that occurred.

\subsubsection{Attention}

The attention of the informants on the kasepuhan palace perceived clean building very well groomed, the people around friendly, the court is very polite. From the very Javanese building, the bricks and carvings on the wall are well-liked and clean. As one of the oldest palaces, there are two white tiger statues as a symbol of a large family alignment. Keraton which became a witness to the spread of Islam, as a citizen Cirebon Informants like when the palace Kasepuhan famous throughout the archipelago even to foreign countries, beautiful atmosphere and ancient objects, as well as unique building motifs. 4.1. 3. Interpretation

Kasepuhan Palace for Cirebon based on a perception of Informant is an icon of Cirebon, as regional assets, with Museum, Architecture Building, Statue of Lion, and know the history of Islam in Cirebon, and much more.

4.2. Perception of Cirebon City People about Kasepuhan Palace to International Destination

\subsubsection{Sensation}

The sensation of Kasepuhan Palace to International Destination according to the informant can scent the Cirebon area. Keraton is much in demand by the public, the historic place is always crowded to attract public interest to 
visit it, such as Sang Ciptarasa Great Mosque, the annual activity of Maulud Prophet Muhammad SAW, so its place will be more crowded visited by the community.

Sensation Kasepuhan Palace as an International Destination can scent the area of Cirebon, from the architecture of Caucasians (Foreign Tourists) is very fond of uniqueness that no other country. Cirebon and Keraton Kasepuhan will get income and the people around will get more income, nothing is impossible as long as the cooperation between the palace with the Government and society of course.

Acceptable things about Keraton Kasepuhan, the pride of its own, The existence of publications is interesting for the community, and there are many mysteries in it that need to be appointed to be published. Agent travel in the city of Cirebon has entered as a must-visit destination, so kasepuhan will be better known and the art that is not owned by the other palace becomes a pride of its own, that is because one of the oldest palace and one of the palace be a witness to the spread of the religion of Islam. With so much charm, Cirebon is ready to become a leading tourist destination.

Things that can be believed about Keraton Kasepuhan towards international destinations according to informants, that:

"Kasepuhan Palace deserves to be a Cirebon icon, because of the history that is very good and can be taken from the positive side. Keraton Kasepuhan used to be a big kingdom and has a board especially in the spread of Islamic Religion, relics of a kingdom "Prabu Siliwangi", holy mosque filled with the positive aura. Psychologically, the number of historic buildings that become the pride of Cirebon community that should be preserved, such as the existence of a building relics whose history makes people curious and interested to visit it ".

One of the palaces that witnessed the milestone of the Islamic empire in Cirebon, which is a milestone and as an icon of the city of Cirebon because the palace kasepuhan is the oldest palace in the archipelago with beautiful architecture to look at, so the palace kasepuhan very possible to be an international destination.

\subsubsection{Attention}

Based on interviews with informants, something of interest is based on the occurrence that, if the palace of Kasepuhan became an International destination, it is a natural thing because there are so many activities of historical values, such as every 1 Syawal train Kencana Paksi Naga Liman issued for bathing and around the palace of many sellers and turning comedy, Keraton Kasepuhan which has a hierarchy of space structure in the form of three levels of arrangement of the core room, the middle room, and the room outside the different, the existence of normal circumstances and the absence of absence of negative events, Changes in time-consuming buildings and changes in policy direction, Place to commemorate Maulud Prophet Muhammad SAW, Praying, and Sholat "Rebo Wekasan".

At the Kasepuhan Palace certainly can make the Cirebon area more advanced than other regions "Informant I states:

"Increasingly crowded, stalled, but income will increase and can provide opportunities for people to do food business or souvenirs typical Cirebon" Informant II states:

"Cirebon can be more developed than other areas, Cirebon is growing, Cirebon will be crowded with many tourists, not demanding the possibility of hotels and clubs will mushroom more."

\subsection{Interpretation}

Things to do Keraton Kasepuhan for international destinations to introduce the Kasepuhan Palace destination not only to the local community but with the community outside Cirebon as well, the publication of the palace kasepuhan with motifs through digital or conventional media, make religious events, commemorate Maulud Nabi, and other positive events.

Thus something that can be done Kasepuhan Palace for its existence is to do the main branding. Preserving the palace Kasepuhan and keep it, repair facilities and infrastructure palace and cleanliness, and, cooperation between the palace with the Government so that goal is achieved.

Informant $\mathrm{V}$ states:

Improvement of facilities and infrastructure, Training of human resources for language proficiency. Manage Keraton to maintain the authenticity of its place, building, and architecture for international tourist destinations The community's trust in Keraton Kasepuhan towards the international destination of Informant I stated: to believe in the effort, so as to be able to international destinations accompanied by the cooperation of various parties.

Keraton Kasepuhan able to become an international destination in the hope not too free, not to lose local wisdom, architectural buildings, 
and objects that are very supportive to be preserved.

4.3. Factor Inhibiting Kasepuhan Palace in Creating Kasepuhan Palace to International Tourism Destination

\section{Informant I stated:}

If there is lack of support from the local government it could be that all discourse takes extra effort from all community groups. "

Kasepuhan Palace party stated as follows:

"There are not many obstacles faced by Public Relations Keraton Kasepuhan, only the delivery of messages tailored to globalization."

Another obstacle as presented by Mr. Iman Sugiman is building maintenance. He argued "Making building easier than building maintenance" which in this case is Kasepuhan Palace Building Care. "

Disporbudpar stated as follows:

"From the aspect of Communicators: The burden of responsibility all governed even though the community participated, limited government budget for tourism; Message Aspect: Maintenance of a tourist object is a common task so people should have a sense of pride in the palace of the elders that is the oldest palace; Media Aspects are no constraints; Aspects Communications have no awareness related to preserving the culture. " Thus if the lack of support from the local government may be all just discourse alone so it takes extra effort from all groups of society, family palace, community, a government must cooperation, the moral and moral support, so that ideals can be achieved well.

\subsection{Factor Supporting Kasepuhan Palace in} Creating Kasepuhan Palace to International Tourism Destination

There are some things that have been done by the palace, Keraton Kasepuhan has many assets that can qualify for international destinations, such as the following:

a. Attractions or Attraction Attractions include historical buildings; historic items and historic manuscripts, such as having antique ceramic relics, relics of king and queen clothes, chariots and others; in addition to the event that is always done, both traditional annual events and special events Keraton Kasepuhan has cooperated with mineral water company in the form of logo (TRTA-Kasepuhan), Bata bara in Indramayu, and with Cirebon Sugar factory (PT.RJWL) with various activities.

\section{b. Tourism Facilities and Accommodation}

The parking lot is adequate, as well as places of worship, toilets and shopping shop is available. Cooperation with PATA and several associations that are related to tourism both local, national and international. Besides that, there is also the flow of tourism, tourism streets are better, the lighting on the road and attractions, the package tourism for dinner with the Sultan (for groups of at least 30 to 40 people), and other facilities.

c. Destination image

Good, but for environmental conditions, because the palace is passed by the river, often tidal. At high tide, the river brings the garbage and recedes the garbage itself, so the suggestions from the palace and the government to the surrounding community and tourists to be improved and returned to their consciousness to maintain the authenticity and integrity in the tourism object.

d. Community Readiness and HR Professionalism Community Preparedness and Human Resource Professionals The community follows the course, conducts guidance on people who participate in tourism, arrangement of swordsmanship, and HR Training as follows: Training, meeting invitations, Tourism Management Group (Kompepar), even the increase in tourism awareness has been carried out in an effort to understand its duty to maintain these attractions.

e. Potential Market owned

Kasepuhan Palace is often covered by Local, National, and International Television Stations, the rest is National and Local TV Station, besides there are other market potential areas such as Sunyaragi Cave, while the leading destinations of religious and nature tourism are the attractions of Gunung Jati Sunan grave. (Mukarto, 2016: 73)

\section{CONCLUSIONS}

1. Perception of Cirebon city community about Keraton Kasepuhan has its own sensation for society both from a building, culture, and social interaction that happened with Attention perceived clean building very well groomed, a friendly surrounding community as well as very polite court administrators. Keraton Kasepuhan as an icon of Cirebon and regional assets.

2. Perceptions of Cirebon city community about Kasepuhan palace in creating Kasepuhan Palace to the International Tourism 
Destination, Kasepuhan Palace can scent the Cirebon area, from its unique architecture which no other country, with its many charms, Cirebon ready to become the leading tourist destination.

3. The constraint factor of the Kasepuhan Palace in Creating the Kasepuhan Palace to the International Tourism Destination is the lack of cooperation between the community, the royal family, the community, the government, the moral and moral support, so that the ideals can be achieved well, as well as on environmental conditions and maintenance authenticity of the building.

4. Factors supporting the Kasepuhan Palace in Creating Kasepuhan Palace to the International Tourism Destination have met the criteria, ranging from tourist attraction, accessibility, stakeholder support, tourism facilities and accommodation, community readiness and human resource professionalism, and community participation in tourism destination development efforts, even the potential of the market that is owned vary, it's just the image of the destination of the environment still needs to be addressed.

\section{REFERENCES AND NOTES}

Kotler, Philip, Marketing Management. Eleventh edition. Jakarta: PT. Index of Gramedia Group, 2008, p-; 250
Mulyana, Dedi, Introduction to Communication Studies an Introduction, Bandung: Youth Rosdakarya, 2008, p-; 180

Morrison, A. M \& Anderson, D. J. Destination Branding, Presented at the Annual Meeting of the Missouri Association of Convention and Visitor Bureaus. 2002, p-; xvii

Rakhmat, Jalaluddin, Communication Research Methods. Bandung: Teens Rosdakarya. 2000, p-; 24

\section{Proceeding}

Mukarto Siswoyo, Farida Nurfalah, Heryani, PR Indonesia for National Awakening: Public Relations Strategy of Kasepuhan Palace in Creating Kasepuhan Palace as Branding Cirebon Towards International Destination Jakarta: Media Pilar Indonesia, 2016, p-; 62

Electronic source:

http://disporbudpar.cirebonkota.go.id/kultur/bu daya/69-trip-waras.html

http : // www.cirebon.kota.co.id

http://www.koransindo.com $/$ news.php? $r=5 \& n=83 \&$ date $=2016$ 01-25

Newspaper :

Mike, Keraton Kasepuhan in SKH Radar Cirebon, Tuesday, October 13, 2015, p .; 29 